\title{
Morphological and anatomical characteristics of Artemisia absinthium var. absinthium and its Polish endemic variety $A$. absinthium var. calcigena
}

\author{
Kamil Konowalik • Agnieszka Kreitschitz
}

Received: 4 July 2011 / Accepted: 31 March 2012/Published online: 27 April 2012

(C) The Author(s) 2012. This article is published with open access at Springerlink.com

\begin{abstract}
The presented studies are focused on the comparative morphological and anatomical analyses of two wormwood varieties, i.e. the typical variety Artemisia absinthium var. absinthium and var. calcigena, endemic to the Pieniny Mountains (Western Carpathians). The studies comprise descriptions of the characteristics of pollen grains and the achene surface, analyses of seed germination rate and slime formation, stem anatomy, and leaf morphology and anatomy. The pollen grain surface is typical for the whole Artemisia genus. The seed coat consists of proper epidermal cells and slime cells, whose presence is related to the ability to form slime in both taxa. The obtained results show some typical xeromorphic features in the stem and leaf structure, which are more strongly pronounced in A. absinthium var. calcigena than in var. absinthium. These features include a continuous periderm layer and lignified pith cells developed in the early stages of growth. Although some differences between the studied taxa exist (e.g., better germination power, number of flower heads, length of pedicels and anatomy), they are rather a manifestation of phenotypic plasticity and habitat influence than the taxonomic identity.
\end{abstract}

Electronic supplementary material The online version of this article (doi:10.1007/s00606-012-0639-z) contains supplementary material, which is available to authorized users.

\section{K. Konowalik (ه)}

Plant Systematics and Evolution, Institute of Botany, University of Regensburg, Universitätsstr. 31, 93053 Regensburg, Bavaria, Germany

e-mail: Kamil.Konowalik@ biologie.uni-regensburg.de

\section{A. Kreitschitz}

Department of Plant Morphology and Development, Institute of Plant Biology, University of Wrocław, Kanonia 6/8,

50-328 Wrocław, Poland

e-mail: skowron@biol.uni.wroc.pl
Based on the results we can state that A. absinthium var. calcigena presents a low position as an independent taxonomic unit and may exemplify a local phenotypic form.

Keywords Asteraceae - Anthemideae - Variety · Phenotypic plasticity $\cdot$ Endemics $\cdot$ Xeromorphy $\cdot$ Pieniny

\section{Introduction}

Endemic plants can be found all over the world, and they define the identity and uniqueness of the local flora. They are distributed unevenly and are usually connected with environments that provide some isolation or constraints on the neighboring areas (Stebbins 1980). Some places such as mountains or islands are rich in endemic plants compared with boreal or arctic regions, which are relatively poor in them. The history of endemism began with the first voyages and flora descriptions contained in the works of the first modern botanists such as Linnaeus or A. de Candolle (Kruckeberg and Rabinowitz 1985). Some of the important factors that limit (define) endemic distribution are: climate, geology, ecology, isolation and the historical aspects of the flora (Kruckeberg and Rabinowitz 1985; Stace 1993; Debussche and Thompson 2003; Mirek and Piękoś-Mirkowa 2009). There are different types of endemic classifications depending on the age, distribution or cytogenetic features (Kruckeberg and Rabinowitz 1985). Research focusing on endemism usually includes comparisons with the closest relative, including aspects such as ecological differentiation or adaptation to a novel habitat (McKay et al. 2001; Debussche and Thompson 2003; Rajakurna 2004). Endemics may be represented by units on a different taxonomical level, e.g.: species (Richards 2003), subspecies (Riley et al. 2010), variety (Kaye 1999) or even form 
(de Wilde and Duyfjes 2007), but on the other hand they should be clearly defined taxa (Mirek and Piękoś-Mirkowa 2009). A low taxonomical level is represented by the wormwood variety Artemisia absinthium L. var. calcigena Rehm., distinguished as endemic to the Pieniny Mountains (Western Carpathians) by Rehmann (1868).

Artemisia absinthium var. calcigena was described as a Polish endemic taxon based only on a few morphological features, distinguishing it from its typical variety. The features that distinguish it from the typical form were given as follows: pubescent plant, elongated and acute leaf lobes, inflorescence with fewer capitula than the typical form and pedicels longer than the flower heads. This variety is associated with the limestone soils characteristic of the Pieniny Mountains (Rehmann 1868). The endemic character of this taxon has been discussed by many authors, but no morphological, anatomical or cytogenetical studies were ever undertaken to verify its position (e.g., Zarzycki 1981; Piękoś-Mirkowa and Mirek 2003). Zarzycki (1976) described var. calcigena as the only natural ecotype dominant in the Pieniny Mountains. It is also considered to be the only native variety of $A$. absinthium occurring in Poland, whereas other localities have a synanthropic character (Żukowski 1971; Mirek et al. 2002). In the last review of Polish endemics (Mirek and Piękoś-Mirkowa 2009), this variety was not included since the authors examined taxa only on the species and subspecies levels, which in their perspective are easier to analyze than the often questionable and difficult to interpret lower taxonomical units.

The genus Artemisia contains many groups of species that are clearly polymorphic. Such traits as the morphology of the leaves or flower heads are clearly heterogeneous, which makes classification difficult (Torrell et al. 1999; Kreitschitz 2003). One of the reasons for such variability may be phenotypic plasticity and the influence of environmental factors, which modify not only the individual specimen, but also separate parts of the plant, e.g., influence the size and shape of the leaves, fruits or stem height (Stace 1993; Sultan 2000; Kreitschitz 2003).

Wormwood (Artemisia absinthium s.l., Asteraceae, Anthemideae) is native to Eurasia and some parts of North Africa, but is nowadays more widespread and occurs in other continents-mostly due to cultivation (Maw et al. 1985; Gams 1987). In Poland this taxon occurs quite commonly in the lowlands, but also reaches lower mountain locations, growing mostly in full light on mesotrophic, dry to fresh sandy soils (Żukowski 1971; Zarzycki et al. 2002). This species has been the subject of a few morphological and anatomical investigations (Mehrota et al. 1990; Rabie et al. 2006; Noorbakhsh 2008), but exhaustive comparative studies that could be the basis of its diversification are still lacking. In our previous research, we showed that at the cytogenetic level A. absinthium var. calcigena did not differ significantly from the typical variety, i.e., var. absinthium (Konowalik et al. 2010). In this article, we present for the first time the morphological and anatomical features of A. absinthium var. calcigena in comparison to its typical variety, namely A. absinthium var. absinthium. The main aim of the studies was to examine the value of morphological and anatomical features of var. calcigena for determination of its taxonomic position.

\section{Materials and methods}

\section{Plant material}

The material comes from the natural populations listed in Table 1. The plant material included: the middle part of the stem, middle leaves, flower heads and mature achenes. The parts of the stem and leaves were fixed in FAA (a mixture of formalin-acetic acid-70 \% alcohol in the proportion 5:5:90), then the material was pretreated appropriately depending on the study. The plant material is deposited in the collections of K. Konowalik and A. Kreitschitz.

\section{Achene characteristics}

Dry, mature achenes were used for the following analyses: size measurements (width, length), sculpture morphology, slime characteristics and germination energy test.

To assess achene size, the widths and lengths of 100 achenes per population were measured in a light microscope using an ocular lens with micrometer scale. The shape of the achene is clavate, and both measurements were taken in the maximum width and length, which were not always coincidental. Afterwards we computed the proportion of length to width for each achene by dividing length by width. We used the optimized Shapiro-Wilk test procedure for normality (Shapiro et al. 1968; Royston 1982), but some populations did not fit normal distribution, even after normalization. As a consequence these data were not normalized, which resulted in dealing with "pure" natural variability. Since normal distribution was not realized, we used a nonparametric Kruskal-Wallis test (Kruskal and Wallis 1952) to infer whether any differences between varieties or populations exist. After detecting significant variation between populations, we identified which groups were the greatest contributors to variation and the significance of the differentiation when comparing each population with one another using multiple comparisons of mean ranks, as described by Siegel and Castellan (1988). The results of the comparison are shown in Table 3. All calculations and statistical analyses of the 
Table 1 Plant material used in the study

\begin{tabular}{|c|c|c|c|c|}
\hline Taxon & Locality & $\begin{array}{l}\text { Abbreviation } \\
\text { used in the text }\end{array}$ & Habitat & Date of collection, collector \\
\hline $\begin{array}{l}\text { A. absinthium } \\
\text { var. } \\
\text { calcigena }\end{array}$ & $\begin{array}{l}\text { Rocks Grabczychy, } 570 \mathrm{~m} \text {, Pieniny } \\
\text { Mts., Poland; } 49^{\circ} 24^{\prime} 24^{\prime \prime} \mathrm{N}- \\
20^{\circ} 25^{\prime} 19^{\prime \prime} \mathrm{E}\end{array}$ & GR & $\begin{array}{l}\text { Calcareous } \\
\text { rocks, scree }\end{array}$ & 7 Oct 2006, Iwona Wróbel (s) \\
\hline $\begin{array}{l}\text { A. absinthium } \\
\text { var. } \\
\text { calcigena }\end{array}$ & $\begin{array}{l}\text { Trzy Korony, } 860 \mathrm{~m} \text {, Pieniny Mts., } \\
\text { Poland; } 49^{\circ} 24^{\prime} 49^{\prime \prime} \mathrm{N}-20^{\circ} 24^{\prime} 49^{\prime \prime} \mathrm{E}\end{array}$ & TK & $\begin{array}{l}\text { Calcareous } \\
\text { rocks, scree, } \\
\text { sward }\end{array}$ & 21 Oct 2008, Iwona Wróbel (s) \\
\hline $\begin{array}{l}\text { A. absinthium } \\
\text { var. } \\
\text { calcigena }\end{array}$ & $\begin{array}{l}\text { Podskalnia Góra, } 650 \mathrm{~m} \text {, Pieniny Mts., } \\
\text { Poland; } 49^{\circ} 24^{\prime} 36^{\prime \prime} \mathrm{N}-20^{\circ} 24^{\prime} 20^{\prime \prime} \mathrm{E}\end{array}$ & PG & Scree, meadow & $\begin{array}{l}22 \text { Sept 2008, Iwona Wróbel and Kamil } \\
\text { Konowalik (p); } 22 \text { Oct 2008, Iwona Wróbel } \\
\text { (s) }\end{array}$ \\
\hline $\begin{array}{l}\text { A. absinthium } \\
\text { var. } \\
\text { absinthium }\end{array}$ & $\begin{array}{l}\text { Czeszów, } 125 \mathrm{~m} \text {, Lower Silesia, } \\
\text { Poland; } 51^{\circ} 22^{\prime} 39^{\prime \prime} \mathrm{N}-17^{\circ} 15^{\prime} 8^{\prime \prime} \mathrm{E}\end{array}$ & $\mathrm{CZ}$ & Sandy meadow & $\begin{array}{l}27 \text { Aug 2008, Agnieszka Kreitschitz (p); } 5 \text { Dec } \\
\text { 2006, Agnieszka Kreitschitz (s) }\end{array}$ \\
\hline $\begin{array}{l}\text { A. absinthium } \\
\text { var. } \\
\text { absinthium }\end{array}$ & $\begin{array}{l}\text { Gałów, } 130 \mathrm{~m} \text {, Lower Silesia, Poland; } \\
51^{\circ} 6^{\prime} 55^{\prime \prime} \mathrm{N}-16^{\circ} 49^{\prime} 30^{\prime \prime} \mathrm{E}\end{array}$ & GA & $\begin{array}{l}\text { Grass between } \\
\text { meadow and } \\
\text { field }\end{array}$ & $\begin{array}{l}19 \text { Sept 2008, Kamil Konowalik and Monika } \\
\text { Sabat (p); } 24 \text { Nov 2007, Kamil Konowalik (s) }\end{array}$ \\
\hline $\begin{array}{l}\text { A. absinthium } \\
\text { var. } \\
\text { absinthium }\end{array}$ & $\begin{array}{l}\text { Chełmek Wołowski, } 107 \mathrm{~m} \text {, Lower } \\
\text { Silesia, Poland; } 51^{\circ} 27^{\prime} 18^{\prime \prime} \mathrm{N}- \\
16^{\circ} 21^{\prime} 43^{\prime \prime} \mathrm{E}\end{array}$ & $\mathrm{CH}$ & $\begin{array}{l}\text { Grass between } \\
\text { road and } \\
\text { railway }\end{array}$ & $\begin{array}{l}21 \text { Sept 2008, Kamil Konowalik (p); } 1 \text { Dec } \\
\text { 2007, Kamil Konowalik (s) }\end{array}$ \\
\hline
\end{tabular}

$s$ collection of seeds, $p$ collection of plant material and specimen

obtained results were done in Statistica 8.0 (StatSoft Inc. 2007).

The achene surface of was studied under a scanning electron microscope (SEM; LEO435VP). For each population we examined at least three achenes. Achenes were mounted directly on the stubs using a double-adhesive tape, and then they were coated with gold particles and observed in SEM.

In order to check the chemical composition and visualize the slime structure, staining reactions were carried out (Table 2).

For the germination energy test, 90 seeds were used for each population in combination of $3 \times 30$ seeds on filter paper in a petri dish. All dishes were placed at room temperature in daylight. To examine the energy of germination $\left(E_{\mathrm{g}}\right)$ the number of seeds that germinated after 5 days was counted $\left(E_{\mathrm{g}}=\right.$ ratio:germinated seeds after 5 days to total

Table 2 Staining reactions

\begin{tabular}{lll}
\hline Staining & Target & Literature \\
\hline Ruthenium red & Pectins & $\begin{array}{c}\text { Filutowicz and } \\
\text { Kużdowicz (1951) }\end{array}$ \\
$\begin{array}{lll}\text { Safranin } \\
\text { Methylene blue }\end{array}$ & $\begin{array}{l}\text { Cellulose, pectins } \\
\text { Cellulose, pectins }\end{array}$ & $\begin{array}{c}\text { Filutowicz and } \\
\text { Kużdowicz (1951) }\end{array}$ \\
$\begin{array}{l}\text { Floroglucyne }+ \\
45 \% \mathrm{HCl}\end{array}$ & Lignine & Braune et al. (1975) \\
$\begin{array}{l}\text { Alcian blue and safranin } \\
\text { Sudan IV }\end{array}$ & Cell walls & Broda (1971) \\
\hline
\end{tabular}

number of seeds), and to measure the strength of germination $\left(S_{\mathrm{g}}\right)$ seeds that germinated after 21 days were counted ( $S_{\mathrm{g}}=$ ratio:germinated seeds after 21 days to total number of seeds). The protocol for the experiment followed the International Regulations of Seed Evaluation (1997).

Pollen grain morphology

The size and the surface of the pollen grains were studied for three populations of A. absinthium var. absinthium (GA, CH, CZ) and one population of A. absinthium var. calcigena (PG). Flower heads were collected at the beginning of the flowering phase. To separate pollen from flowers, material was macerated in hot $10 \% \mathrm{KOH}$ solution for $2 \mathrm{~min}$. For each population 100 pollen grains were measured in the pole position. To infer statistical differences between them, a one-way ANOVA test was calculated (Finn 1974, 1977).

The surface of the pollen grains was examined under SEM (LEO435VP). The pollen grains were separated from the flower on the microscope slides and mounted directly onto stubs using double-adhesive tape, then coated with gold particles and observed in SEM.

Shoot morphology and anatomy

Young, 6-10-week-old seedlings, obtained from germinating achenes, and middle-stem leaves previously collected in the field were used for the morphological analyses. The material came from all of the populations of $A$. absinthium var. absinthium, and for A. absinthium var. calcigena came 


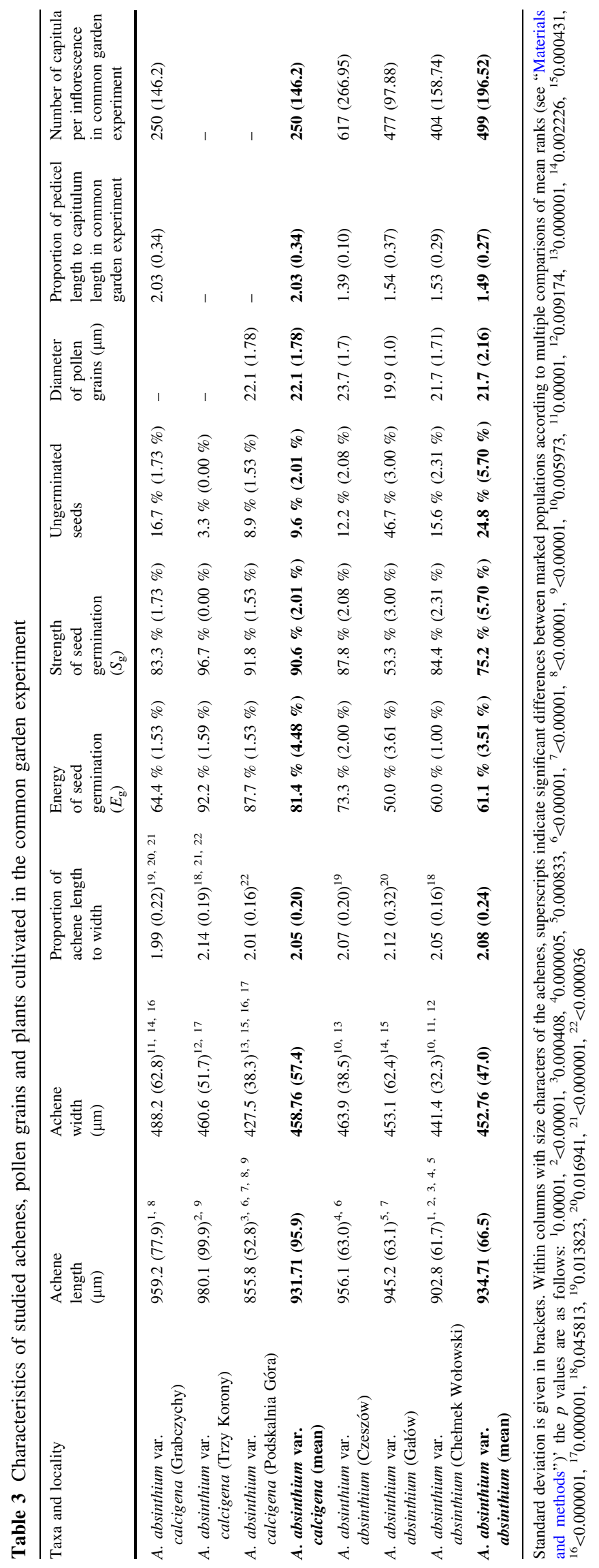


only from one population (PG). The analyses for seedlings were done for at least five individuals per location.

Morphological analysis of leaves was done for seedlings and adult plants. Anatomical investigations of mature leaves were done on the cross sections of the leaf fragments. Material fixed in FAA was prepared according to the standard protocols for embedding in paraffin (O'Brien and McCully 1981). A series of transverse sections, $7 \mu \mathrm{m}$ thick, were cut on a Leica RM 2135 rotary microtome (Leica Instruments, GmbH, Germany) and double stained with safranin and fast green (O'Brien and McCully 1981).

To examine structural details, fresh (seedlings) and mature shoots fixed in FAA were stained with different reagents (Table 2).

\section{Common garden experiment}

To compare the stability of the anatomical details, plants were cultivated under identical conditions. The common garden experiment was situated in Górzyn (Lower Silesia, Poland). Seedlings, grown at room conditions for 6 months, were transferred to the garden and planted in rows. The garden was placed in full sunlight on lessive soil covered with $30 \mathrm{~cm}$ of sand. After being established in the ground, plants were left untended except for occasional weed removal. In the second year after flowering, the height and number of shoots were scored, and the upper parts of the plants were cut and dried. They were used to evaluate two characters used in the original description of the var. calcigena by Rehmann (1868): the length of pedicels and the number of flower heads in inflorescence. For each measurement we used a minimum of five plants for each population and variety. The number of flower heads was counted only in the main inflorescence. In the same inflorescence, lengths of at least ten randomly chosen pedicels and capitula were measured. The leaf shape was not analyzed because of the high variability observed within the taxon (Supplementary material 1).

In addition, the samples of plants coming from the garden experiment were collected, sectioned and stained similarly to the plant material collected from the natural stands (Supplementary material 1).

\section{Results}

Achene morphology

\section{Achene size and surface}

The mean size of the achenes was $934.71 \mu \mathrm{m}$ length and $452.76 \mu \mathrm{m}$ width in var. absinthium, and $931.71 \mu \mathrm{m}$ length and $458.76 \mu \mathrm{m}$ width for var. calcigena (Table 3 ).
Statistical differences were noted between all populations in the case of length (Kruskal-Wallis $H=166.6292, p<$ 0.001), width (Kruskal-Wallis $H=80.49969, p<0.001$ ) and proportion of length to width (Kruskal-Wallis $H=39.26610, p<0.001$ ), but no differences were detected between varieties studied in either length (Kruskal-Wallis $H=1.002757, p=0.3166$ ), width (Kruskal-Wallis $H=$ $1.016988, p=0.3132$ ) or proportion of length to width (Kruskal-Wallis $H=2.476208, p=0.1156$ ) (Table 3).

The achenes of both varieties are very similar to each other. The end of the achene, where it is attached to the receptacle, has a collar composed of 3-5 rows of cells (Fig. 1c, d). On the opposite end, where the corolla is attached to the achene, the slime and epidermal cells form a very delicate rim (Fig. 1c, d). Achenes are glabrous and glossy, with two types of distinguishable cells: rectangular slime cells, arranged in columns along the long axis of the seed (Fig. 1e, f), and proper epidermal cells with an elongated shape, which are spread between the columns of the slime cells (Fig. 1e, f). The surface of the slime cells is characterized by delicate longitudinal lines stretching along the achene.

\section{Slime}

After hydration, all achenes showed a capacity for slime formation. The slime was of the cellulose type. Its main components were pectins, with an additional cellulose skeleton, which was visible after hydration as spiral threads (Fig. 2a). Formation of the slime envelope occurred immediately after contact with water, and within 2-3 min, slime cells split open and pectins, with cellulose threads, formed a narrow slime envelope surrounding the achene. Upon slime envelope formation the cellulose threads did not stretch and stayed coiled. Sometimes the slime cells did not even release the slime, but remained swollen (Fig. 2b). The cellulose slime type described for analyzed taxa is typical for the Artemisia genus and has been previously reported for A. absinthium (Mouradian 1995; Kreitschitz 2003; Kreitschitz and Vallès 2007).

\section{Energy and strength of germination}

Seeds from all populations showed high rates of energy and strength of germination. We noted the highest value for A. absinthium var. calcigena, where the mean rate of $E_{\mathrm{g}}$ reached $81.4 \%$ and $S_{\mathrm{g}} 90.6 \%$. Two populations specifically, i.e. from PG and TK, had the highest values of $S_{\mathrm{g}}$, ranging from 91.8 to $96.7 \%$. For A. absinthium var. absinthium the mean rate of $E_{\mathrm{g}}$ reached $61.1 \%$ and $S_{\mathrm{g}} 75.2 \%$ (Table 3 ). Generally var. calcigena showed a higher energy of germination (ca. $20 \%$ up) and higher strength of germination (ca. $25 \%$ up), and within this 

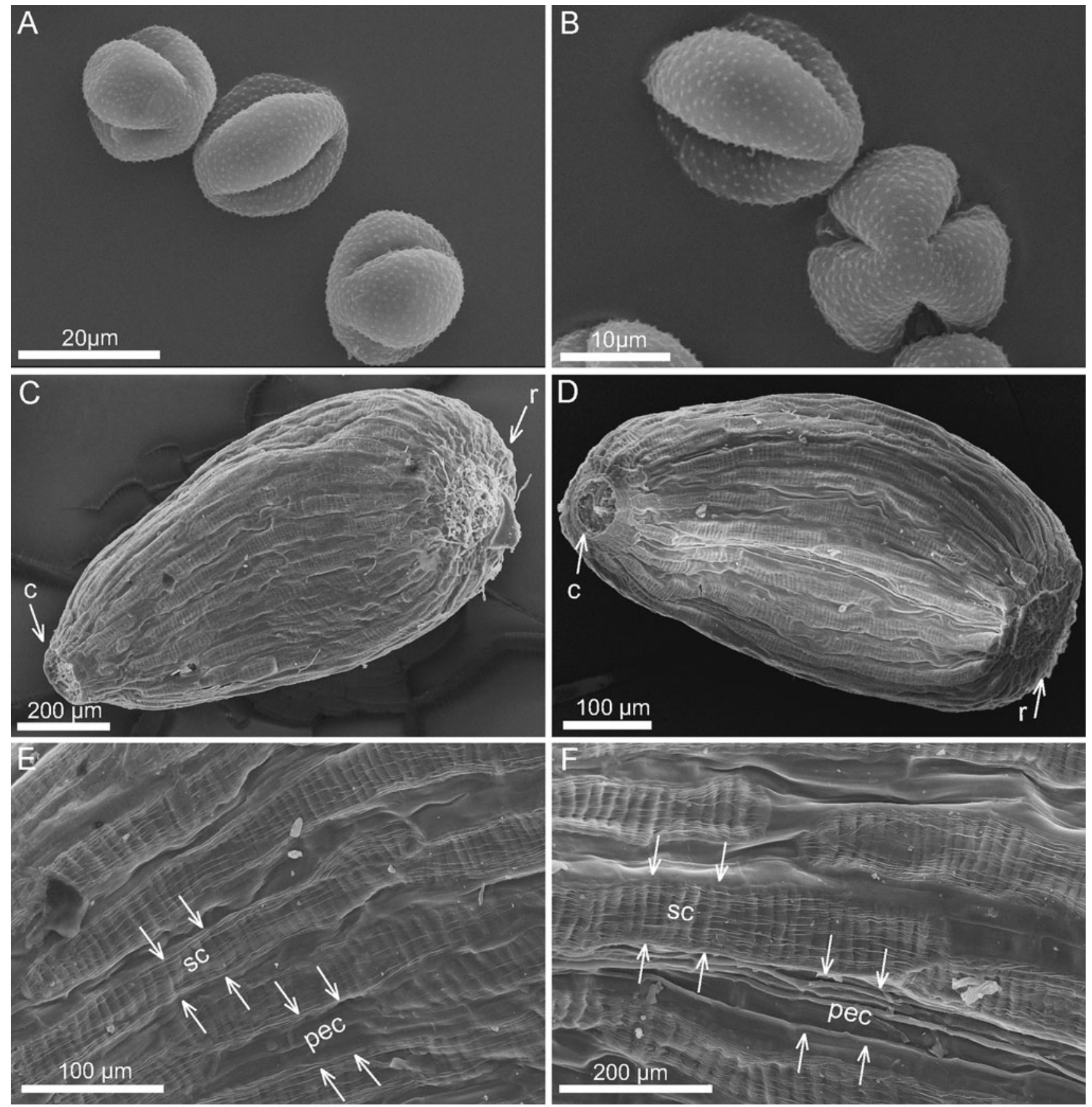

Fig. 1 (a-f) Morphology of pollen grains and achenes: (a, c, e) Artemisia absinthium var. absinthium, (b, d, f) Artemisia absinthium var. calcigena. $c$ collar, pec proper epidermal cells, $r$ rim, $s c$

variety only ca. $10 \%$ of all the seeds did not germinate or were attacked by mold.

\section{Morphology and surface of the pollen grains}

The mean size of pollen grains in var. calcigena was $22.1 \mu \mathrm{m}$ and in the typical variety $21.7 \mu \mathrm{m}$ (Table 3 ). slime cells. Arrows show the columns of the slime cells and proper epidermal cells spread between them

Variation in pollen size between all studied populations was confirmed by the statistical analysis [ANOVA $F_{\text {ratio }}=$ $97.2\left(F_{\text {critical }}=2.63\right) p<0.001$, Fisher's least significant difference $=0.44 \mu \mathrm{m}]$, but no differences between var. absinthium and var. calcigena were noticed [ANOVA $F_{\text {ratio }}=2.02\left(F_{\text {critical }}=2.63\right) \quad p=0.16$, Fisher's least significant difference $=0.58 \mu \mathrm{m}]$. 

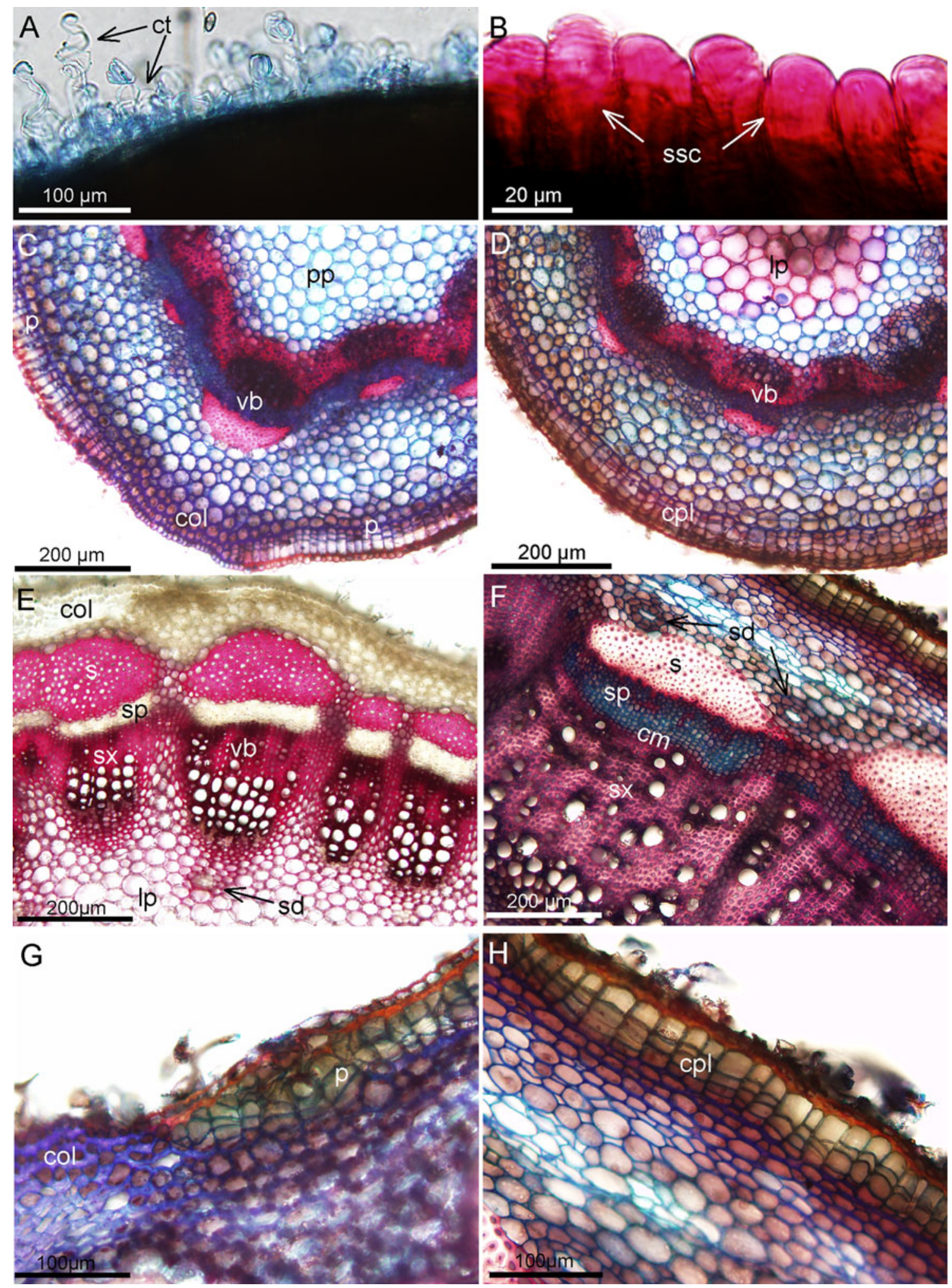

Fig. 2 Anatomical details of Artemisia absinthium var. absinthium $(\mathbf{a}, \mathbf{c}, \mathbf{e}, \mathbf{g})$ and Artemisia absinthium var. calcigena $(\mathbf{b}, \mathbf{d}, \mathbf{f}, \mathbf{h})$. (a-b) Detection of the slime in the achenes, $(\mathbf{c}-\mathbf{h})$ cross section of the stem, (c-d) 10-week-old seedlings, (e-h) adult plants. $\mathrm{cm}$ cambium,

col collenchyma, $c p l$ continuous periderm layer, $c t$ cellulose threads, $l p$ lignified pith, $p$ periderm, $p p$ parenchymatic pith, $s d$ secretory ducts, $s$ sclerenchyma, $s p$ secondary phloem, $s s c$ swollen slime cells, $s x$ secondary xylem, $v b$ vascular bundle 
The microrelief of pollen grains in all of the plants showed no differences between the populations and taxa. The pollen type with three colpi and three pores, one inside each colpus was observed in all of the pollen grains analyzed. Grains in a pole position had a circular shape, in comparison to an equatorial position, in which they are more elongated. The surface was rugged and covered with very short spines (Fig. 1a, b). The exine ornamentation of pollen grains was typical for Artemisia, which is conserved within the whole genus, and even with some of the related genera (Praglowski 1971; Vallès and Seoane-Camba 1988; Martín et al. 2001; Martín et al. 2003; Sanz et al. 2008).

\section{Morphology and anatomy of leaves}

No significant differences in the micromorphology or anatomy of the leaves were observed between either variety. The leaves were covered by glandular and covering trichomes on both sides. The observed differences between leaves of seedlings and mature plants were related to the progression of the developmental stages. Seedlings were very sparsely covered by " $T$ "-shaped covering trichomes, whereas mature leaves were characterized by a thick layer of them, forming a tomentose and silky cutner on a leaf abaxial surface. Glandular hairs occurred sparsely on both leaf surfaces. A difference in the color of the leaves was observed. In A. absinthium var. absinthium from the GA population, plants exhibited a dark green color with slightly silver covering, whereas plants from $\mathrm{CH}$ and $\mathrm{CZ}$ had silvery leaves. All the plants of var. calcigena had a more silvery color, which may suggest that trichomes may form a denser layer in this variety.

Stomata are localized only on the abaxial side of the leaf, and sometimes they may emerge above the level of the epidermis. The epidermis was covered by a thin layer of cuticle. The anticlinal cell walls of the epidermal cells have a wavy-shaped outline.

Leaf cross sections in all specimens studied presented a similar structure, typical of a bifacial leaf, and no special features or differences were observed between varieties. However, on the adaxial side where typically one layer of palisade mesophyll occurred in some places, two layers could be visible. At the same time at the abaxial side the spongy mesophyll with intercellular spaces occurred.

\section{Anatomy of the stem}

The cross sections of seedlings presented a typical primary structure of the shoot (Fig. 2c, d). Seedlings of var. absinthium (populations $\mathrm{CH}$ and GA) showed 1-2 continuous layers of collenchyma developed under the epidermis. Additionally, at this early stage, phellogen started developing in the subepidermal layer alternating with collenchyma (population CZ) (Fig. 2c). On the contrary in var. calcigena phellogen formed a continuous periderm layer, whereas collenchyma was lacking (Fig. 2d). The abundance of sclerenchymatic tissue was observed around vascular bundles, particularly in var. absinthium from $\mathrm{CZ}$ (Fig. 2c), and in all populations of var. calcigena (Fig. 2d). Moreover, parenchyma cells of the pith in var. calcigena were lignified (Fig. 2d). Secretory ducts started to develop in the seedlings, close to the vascular bundles, at both of their sides (Fig. 2e, f) similarly in both taxa.

In mature plants the stem structure was similar to that of the seedlings, but the parenchyma cells of the pith were much more strongly lignified, and many lignified sclerenchymatic fibers were present in both of the varieties (Fig. 2e, f). Also the secondary structure with secondary phloem and xylem could be observed in mature plants (Fig. 2e, f). Furthermore, the periderm, which started to develop in seedlings, was also formed as a discontinuous layer, alternating with collenchyma (var. absinthium $\mathrm{CZ}$, GA) (Fig. 2g) or more pronounced as a continuous layer (var. calcigena) (Fig. 2h). In some populations of var. absinthium $(\mathrm{CH})$, no signs of periderm were observed even in mature plants.

\section{Common garden experiment}

Plants exhibited a similar appearance with slight differences concerning more whitish leaves in var. calcigena, suggesting denser coverage of trichomes in this variety. The leaf shape was very variable among plants within and between populations (Supplementary material 1), which confirmed the weakness of this character in distinguishing two varieties. The proportion between lengths of pedicel and capitulum was different among populations (KruskalWallis $H=8.653855, p=0.034$ ), and it was caused mainly by differences between $\mathrm{CZ}$ and GR populations ( $p=0.04$, according to multiple comparisons of mean ranks) (Table 3). We also noted significant differences between two varieties (Kruskal-Wallis $H=8.100543$, $p=0.004$ ), and pedicels in var. calcigena were longer compared to the typical variety. The number of capitula in inflorescence was also statistically different among populations (Kruskal-Wallis $H=8.744589, p=0.033$ ) and caused by differences between $\mathrm{CZ}$ and GR populations ( $p=0.04$, according to multiple comparisons of mean ranks) (Table 3). The differences between two varieties were also significant (Kruskal-Wallis $H=6.206061$, $p=0.013$ ) where the number of capitula in inflorescence was smaller in var. calcigena.

The structure of the plants coming from the garden experiment was comparable to the specimens collected from the natural habitats (Supplementary material 1). A typical stem with parenchymatic cortex, vascular 
bundles (eustela) and lignified pith was observed. Secretory ducts were present at both sides of the vascular bundles. The periderm was still observed in var. absinthium (CZ, GA), but it was less pronounced than in plants coming from natural localities. In one population $(\mathrm{CH})$, there was no periderm, although it had been present before. In all of the studied var. calcigena plants, the periderm was no longer formed as a continuous layer as it had been previously, but formed short discontinuous strips similarly to var. absinthium from $\mathrm{CZ}$ and GA.

\section{Discussion}

All of the data that may show the differences between species or lower taxa have great taxonomical meaning. Among them morphological and anatomical studies are very valuable, giving many different details, which may be used for objective taxonomical analysis (Stace 1993). Plants are highly plastic, and individuals within a species can demonstrate morphological, physiological and anatomical variability related to environmental conditions (Callaway et al. 2003; Valladares et al. 2007). The recognition of this phenomenon is very important in the proper establishment of the taxonomical position for studied plants (Stace 1993).

Morphological variability in genus Artemisia is a known phenomenon and occurs at different organizational levels (Torrell et al. 1999; Kreitschitz 2003). The most variable feature within the studied specimens, as in other Atremisia taxa, was the morphology of leaves. Artemisia leaves often differ in form along the stem of one plant and also show variation between single specimens (Supplementary material 1) (Kreitschitz 2003). Thus, because of their changeable macromorphology, this feature needs to be treated cautiously.

It can be expected in an endemic unit (Mirek and Piękoś-Mirkowa 2009) that the plants studied will demonstrate some characteristic features that allow distinguishing the endemic taxon from the typical form of A. absinthium. However, the results presented here revealed only minor differences on the morphological and anatomical levels. In our previous work (Konowalik et al. 2010) cytogenetic and molecular studies (chromosomal morphology, ITS and ETS sequence analysis) were done for the same plant samples and did not reveal any significant differences. Furthermore, the present studies also did not confirm the taxonomical peculiarity of the populations described as the endemic variety calcigena. Some of the observed features of the Pieniny populations suggest rather that populations are well adapted to their local environment (McKay et al. 2001; Grivet et al. 2011).
Within Artemisia, we can find endemic taxa as well as endemic infrageneric units such as the subgenus Tridentatae, which is restricted to western parts of North America (McArthur et al. 1981; Garcia et al. 2008). In Polish flora such a character was postulated for populations of A. absinthium var. calcigena occurring in the Pieniny Mountains. After the last revisions of the Pieniny Mountain flora, this taxon lost its endemic position, and only two species have been recognized as endemics in the newest quantifications (Piękoś-Mirkowa and Mirek 2003; Mirek and Piękoś-Mirkowa 2009; Piękoś-Mirkowa and Mirek 2010). Following the criteria of Mirek and Piękoś-Mirkowa (2009), who classified only plants at the species level as being endemic (in case of subspecies only well-verified taxa were considered) and regarding the variability within species as a source for taxonomic differentiation, the endemic position of A. absinthium var. calcigena could be disputable.

Phenotypic plasticity is a source of numerous morphological and anatomical variations that may promote adaptive divergence (McKay et al. 2001; Callaway et al. 2003; Valladares et al. 2007). Taxa from the Artemisia genus occur in a wide range of different habitats, although most of them are dominant in dry areas (Bremer and Humphries 1993; Polyakov 1995). Thus, many of them have developed diverse adaptations, which often have a xeromorphic character (Lyshede 1979; Metcalfe and Chalk 1979). For instance, in different habitats and under water stress conditions, A. absinthium may exhibit different morphological forms manifested, e.g., by the color of the plants, which can change from vivid green in moist conditions to gray-green in dry habitats (Johnson 1975; Maw et al. 1985). We observed that plants from the Pieniny Mountains have a gray-silver hue, probably because of a thick layer of covering trichomes at the leaf surface. Such a dense cover of dead trichomes is a known feature in xeromorphic plants, which adapts to dry conditions by limiting transpiration, reflecting strong radiation or even helping to absorb water (Lyshede 1979). Pubescence may also participate in the control of water loss and temperature regulation (Johnson 1975).

Variability in achene and pollen grains size in A. absinthium has been described by some authors (Singh and Joshi 1969; Praglowski 1971; Maw et al. 1985; Vallès and Seoane-Camba 1988; Kreitschitz 2003). It may be a result of different factors, e.g., a consequence of environmental conditions (Grzesiuk and Kulka 1981) expressing adaptations to specific (including xerothermic) habitats (Silverton 1989). Other features observed for the achenes, such as the surface sculpture or the energy and strength of germination, are typical of Artemisia and are in accordance with earlier data (Maw et al. 1985; Vallès and Seoane-Camba 1988; Kreitschitz 2003; Kreitschitz and Vallès 2007). 
The observed ability to form a slime envelope is characteristic of many Artemisia taxa (Grubert 1974; Mouradian 1995; Kreitschitz and Vallès 2007). Although in the studied material the slime envelope was not so abundant in comparison to other Artemisia species, it should be sufficient for seed germination in dry habitats in which the studied taxa typically occur. It has been reported that the presence of slime facilitates germination in the areas with limited water availability (Huang and Gutterman 1999; Huang et al. 2000; Kreitschitz 2009).

At the anatomical level no distinct differences or special features were observed between both studied taxa. The studies revealed rather xeromorphic features in the stem anatomy, which could be more of an adaptation than taxonomic difference. A continuous layer of periderm formed in the early stage of development and lignification of pith cells, which characterized var. calcigena, may be an effect of the dry calcareous habitat. In contrast, var. absinthium, which grows in less dry, non-exposed locations, did not form the periderm. Only plants from the $\mathrm{CZ}$ population formed a discontinuous periderm ring, which may suggest that these plants represent an intermediate level of xeromorphic features. Similar processes, i.e., periderm formation and the lignification of pith cells, were observed, e.g., in Spartocytisus and Genista, which are typical xerophytes (Lyshede 1979), which may confirm the adaptive significance of these features for plants growing in dry habitats. Furthermore, the results of the garden experiment seem to confirm this observation. The cultivation of plants from different populations and varieties made them relatively uniform, suggesting the impact of the environment on the appearance of some features, e.g., a continuous periderm ring. Other differences could be maintained even when the same environmental conditions were applied to plants and were a result of interspecific variation occurring between natural populations. This could suggest the influence of natural selection (Øvstedal and Mjaavatten 1992; Pregitzer et al. 2010).

The described results have documented the great adaptive potential of the studied plants to different environmental conditions. Taking into consideration all the data obtained so far from the different analyses, it may be stated that the var. calcigena, in comparison to the typical variety, has not demonstrated any strong distinct features, which may classify this variety as an independent unit.

It is suggested that phylogeographical and ecological research (including the whole or at least a broader range of the species) are necessary to establish the range of variability and taxonomic positions for lower taxa included in the $A$. absinthium s.l. group.

Acknowledgments We are very thankful to Mrs. Iwona Wróbel from Pieniny National Park for collecting seeds of the endemic variety, help in collecting plants and for kind help in gathering information. Plants and seeds from Pieniny National Park were collected under permission no. PB-5132-24/08 (44/08) under the direction of the park. We would like to thank our colleagues, particularly Dr. Edyta Gola, from the Department of Plant Morphology and Development (University of Wrocław) for the help provided during the research and comments on the article.

Open Access This article is distributed under the terms of the Creative Commons Attribution License which permits any use, distribution, and reproduction in any medium, provided the original author(s) and the source are credited.

\section{References}

Braune W, Leman A, Taubert H (1975) Praktikum z anatomii roślin. PWN, Warszawa

Bremer K, Humphries C (1993) Generic monograph of the Asteraceae-Anthemideae. Bull Nat Hist Mus London, Bot 23:71-177

Broda B (1971) Metody histochemii roślinnej. PWZL, Warszawa

Callaway RM, Pennings SC, Richards CL (2003) Phenotypic plasticity and interactions among plants. Ecology 84(5):11151128

Debussche M, Thompson JD (2003) Habitat differentiation between two closely related mediterranean plant species, the endemic Cyclamen balearicum and the widespread C. repandum. Acta Oecologica 24(1):35-45

de Wilde WJJO, Duyfjes BEE (2007) Gynostemma (Cucurbitaceae) in Thailand and Malesia. Blumea. Biodivers Evol Biogeogr Plants 52(2):263-280

Filutowicz A, Kużdowicz A (1951) Mikrotechnika roślinna. PWR i L, Warszawa

Finn JD (1974) A general model for multivariate analysis. Holt, Rinehart \& Winston, New York

Finn JD (1977) Multivariate analysis of variance and covariance. In: Enslein K, Ralston A, Wilf HS (eds) Statistical methods for digital computers, vol III. Wiley, New York, pp 203-264

Gams H (1987) Artemisia L. In: Hegi G Illustrierte (ed) Flora von Mittel-Europa, Spermatophyta, Band VI, Angiospermae, Dicotyledones 4, Teil 4. Verlag Paul Parey, Hamburg, pp 626-674

Garcia SM, Garnatje T, Pellicer J, Siljak-Yakovlev S, McArthur ED, Vallès J (2008) Ribosomal DNA, heterochromatin, and correlation with genome size in diploid genome size and polyploid North American endemic sagebrushes (Artemisia, Asteraceae). Genome 52:1012-1024

Gerlach D (1972) Zarys Mikrotechniki Botanicznej. PWR i L, Warszawa

Grivet D, Sebastiani F, Alía R, Bataillon T, Torre S, Zabal-Aguirre M, Vendramin GG, González-Martínez SC (2011) Molecular footprints of local adaptation in two mediterranean conifers. Mol Biol Evol 28(1):101-116

Grubert M (1974) Studies of distribution of myxospermy among seeds and fruits of Angiospermaceae and its ecological importance. Acta Biologica Venezuelica 8:315-551

Grzesiuk S, Kulka K (1981) Fizjologia i Biochemia nasion. PWR i L, Warszawa

Huang Y, Gutterman Z (1999) Water absorption by mucilaginous achenes of Artemisia monosperma: floating and germination as affected by salt concentrations. Israel J Plant Sci 47:27-34

Huang Z, Gutterman Y, Hu Z (2000) Structure and function of mucilaginous achenes of Artemisia monosperma inhabiting the Negev Desert of Israel. Israel J Plant Sci 48:255-266 
International regulations of seed evaluation (1997) Instytut Hodowli i Aklimatyzacji Roślin w Radzikowie, Radzików (translation to Polish)

Johnson HB (1975) Plant pubescence: an ecological perspectives. Bot Rev 41(3):233-253

Kaye TN (1999) From flowering to dispersal: reproductive ecology of an endemic plant, Astragalus australis var. olympicus (Fabaceae). Am J Bot 86(9):1248-1256

Konowalik K, Garcia S, Pellicer J, Kreitschitz A, Vallès J (2010) Cytogenetic characterisation of Artemisia absinthium (Asteraceae, Anthemideae) and its Polish endemic var. calcigena. Annales Botanici Fennici 47(6):477-488

Kreitschitz A (2003) Zróżnicowanie morfologiczne i cytologiczne wybranych gatunków rodzaju Artemisia L. z Dolnego Śląska. Wydział Nauk Przyrodniczych, Uniwersytet Wrocławski, Wrocław (PhD thesis)

Kreitschitz A, Vallès J (2007) Achene morphology and slime structure in some taxa of Artemisia L. and Neopallasia L. (Asteraceae). Flora 202:570-580

Kreitschitz A (2009) Biological properties of fruit and seed slime envelope-how to live, fly, and not die. In: Gorb NS (ed) Functional surfaces in biology, vol 1-2, Springer, Berlin, pp 11-30

Kruckeberg AR, Rabinowitz D (1985) Biological aspects of endemism in higher plants. Ann Rev Ecol Syst 16:477-479

Kruskal W, Wallis WA (1952) Use of ranks in one-criterion variance analysis. J Am Stat Assoc 47(260):583-621

Lyshede OB (1979) Xeromorphic features of three stem assimilants in relation to their ecology. Bot J Linn Soc 78:85-98

Martín J, Torrell M, Vallès J (2001) Palynological features as a systematic marker in Artemisia L. and related genera (Asteraceae, Anthemideae). Plant Biol 3:372-378

Martín J, Torrell M, Korobkov AA, Vallès J (2003) Palynological features as a systematic marker in Artemisia L. and related genera (Asteraceae, Anthemideae), II: implications for subtribe Artemisiinae delimitation. Plant Biol 5:85-93

Maw MG, Thomas AG, Stahevitch A (1985) The biology of Canadian weeds. 66. Artemisia absinthium L. Can J Plant Sci 65:389-400

McArthur ED, Pope CL, Freeman DC (1981) Chromosomal studies of subgenus Tridentatae of Artemisia: evidence of autopolyploidy. Am J Bot 68(5):589-605

McKay JK, Bishop JG, Lin J-Z, Richards JH, Sala A, Mitchell-Olds T (2001) Local adaptation across a climatic gradient despite small effective population size in the rare sapphire rockcress. Proc R Soc Lond B Biol Sci 268(1477):1715-1721

Mehrotra S, Mehrotra BN, Aswal BS, Dharma HP (1990) Leaf surface studies of some medicinal Artemisias. Int J Crude Drug Res 28(2):103-119

Metcalfe CR, Chalk L (1979) Anatomy of dicotyledons. Systematic anatomy of the leaf and stem. Clarendon Press, Oxford

Mirek Z, Piękoś-Mirkowa H, Zając A, Zając M (2002) Flowering plants and pteridophytes of Poland. A checklist. Biodiversity of Poland vol 1. Szafer Institute of Botany, Polish Academy of Sciences, Kraków

Mirek Z, Piękoś-Mirkowa H (2009) Fitogeograficzne aspekty endemizmu w Polsce. Wiad Bot 53(3/4):7-30

Mouradian LG (1995) Comparative morpho-anatomical investigation of the achenes of Filifolium Kitam. and related genera. In: Hind DJN, Jeffrey C, Pope GV (eds) Advances in compositae systematics. Royal Botanic Gardens, Kew, pp 41-49

Noorbakhsh N, Ghahreman A, Tatar F, Mahdigholi K (2008) Leaf anatomy of Artemisia (Asteraceae) in Iran and its taxonomic implications. Iran J Bot 14(1):54-69

O'Brien TP, McCully ME (1981) The study of plant structure principles and selected methods. Bradfort House Pty. Ltd., South Melbourne
Øvstedal DO, Mjaavatten O (1992) A multivariate comparison between three NW. European populations of Artemisia norvegica (Asteraceae) by means of chemometric and morphometric data. Plant Syst Evol 181(1):21-32

Piękoś-Mirkowa H, Mirek Z (2003) Endemic taxa of vascular plants in the Polish Carpathians. Acta Societatis Botanicorum Poloniae 72(3):235-242

Piękoś-Mirkowa H, Mirek Z (2010) Threat to endemic vascular plants occurring in Poland and their conservation. Chrońmy Przyrode Ojczystą 66(1):15-26

Polyakov PP (1995) Artemisia L. In: Flora of the USSR, vol 26. English edition: Bischen Singh, Mahendra Pal Singh. Koeltz Scientific Books, Germany, pp 488-723

Praglowski J (1971) The pollen morphology of the Scandinavian species of Artemisia L. Pollen Spores 13(3):381-404

Pregitzer C, Bailey J, Hart S, Schweitzer J (2010) Soils as agents of selection: feedbacks between plants and soils alter seedling survival and performance. Evol Ecol 24(5):1045-1059

Rabie M, Jalili A, Zarrinkamar F (2006) Anatomical characteristics of five Artemisia species in the north of Iran. Pajouhesh Sazandegi 70:79-87

Rajakurna N (2004) The edaphic factor in the origin of plant species. Int Geol Rev 46:471-478

Rehmann A (1868) Botanische Fragmente aus Galizien. Verhandlungen der Zoologisch-Botanischen Gesellschaft in Wien 18:479-506

Richards A (2003) Physiological profiles of restricted endemic plants and their widespread congenors in the North Queensland wet tropics, Australia. Biol Conserv 111(1):41-52

Riley L, McGlaughlin M, Helenurm K (2010) Genetic diversity following demographic recovery in the insular endemic plant Galium catalinense subspecies acrispum. Conserv Genet 11(5):2015-2025

Royston JP (1982) An extension of Shapiro and Wilks' W test for normality to large samples. Appl Stat 31:115-124

Sanz M, Vilatersana R, Hidalgo O, Garcia-Jacas N, Susanna A, Schneeweiss GM, Vallès J (2008) Molecular phylogeny and evolution of floral characters of Artemisia and allies (Anthemideae, Asteraceae): evidence from nrDNA ETS and ITS sequences. Taxon 51(1):1-13

Shapiro SS, Wilk MB, Chen HJ (1968) A comparative study of various tests of normality. J Am Stat Assoc 63:1343-1372

Siegel S, Castellan NJ (1988) Nonparametric statistics for the behavioral sciences, 2nd edn. McGraw-Hill, New York, pp 213-215

Silverton J (1989) The paradox of seed size and adaptation. Tree $4(1): 24-26$

Singh G, Joshi RD (1969) Pollen morphology of some Eurasian species of Artemisia. Grana Palynologica 9:1-3

Stace CA (1993) Taksonomia roślin i biosystematyka. PWN, Warszawa

Stebbins GL (1958) Zmienność i ewolucja roślin. PWN, Warszawa

Stebbins GL (1980) Rarity of plant species: a synthetic viewpoint. Rhodora 80:77-86

Sultan SE (2000) Phenotypic plasticity for plant development, function and life history. Trends Plant Sci 5(12):537-542

Torrell M, Garcia-Jacas N, Susanna A, Vallès J (1999) Phylogeny of Artemisia (Asteraceae-Anthemideae) inferred from nuclear ribosomal DNA (ITS) sequences. Taxon 48:721-736

Valladares F, Gianoli E, Gómez JM (2007) Ecological limits to plants phenotypic plasticity. New Phytol 12:537-542

Vallès J, Seoane-Camba JA (1988) Estudis carpologics en el genere Artemisia L. a la Peninsula Iberica i les Illes Balears. Actes del Simposi Internacional de Botanica Pius Font i Quer. Fanerogamia 2:211-215 
Zarzycki K (1976) Małe populacje pienińskich roślin reliktowych i endemicznych, ich zagrożenie i problemy ochrony. Ochrona Przyrody 41:7-75

Zarzycki K (1981) Rośliny naczyniowe Pienin. Rozmieszczenie i warunki występowania. Państowowe Wydawnictwo Naukowe, Warszawa-Kraków

Zarzycki K, Trzcińska-Tacik H, Różański W, Szeląg Z, Wołek J, Korzeniak U, (2002) Ecological indicator values of vascular plants of Poland. Biodiversity of Poland vol. 2. Szafer Institute of Botany, Polish Academy of Sciences, Kraków

Zukowski W (1971) Artemisia L., Bylica. In: Pawłowski B, Jasiewicz A (eds) Flora Polska-Rośliny Naczyniowe Polski i Ziem Ościennych, vol 12. Państwowe Wydawnictwo Naukowe, Warszawa-Kraków, pp 288-304 